\title{
Hydroids (Cnidaria, Hydrozoa) collected on the inner continental shelf of the state of Rio de Janeiro, Brazil, during the Oceanographic Operations GEOCOSTA RIO I and II
}

\author{
Priscila Araci Grohmann ${ }^{1,2}$, Claudio do Carmo Nogueira ${ }^{1}$ \& Vera Maria Abud Pacífico da Silva ${ }^{1}$ \\ ${ }^{1}$ Departamento de Zoologia, Instituto de Biologia, Universidade Federal do Rio de Janeiro - UFRJ, \\ CCS - Bloco A - Ilha do Fundão, CEP 21941-590, Rio de Janeiro, RJ, Brazil \\ ${ }^{2}$ Corresponding author: Priscila Araci Grohmann, e-mail: grohmann@biologia.ufrj.br
}

GROHMANN, P.A., NOGUEIRA, C.C. \& SILVA, V.M.A.P. Hydroids (Cnidaria, Hydrozoa) collected on the inner continental shelf of the state of Rio de Janeiro, Brazil, during the Oceanographic Operations GEOCOSTA RIO I and II. Biota Neotrop. 11(2): http://www.biotaneotropica.org.br/v11n2/en/ abstract?article+bn03711022011

\begin{abstract}
The Brazilian Navy (DHN/MB) commissioned a series of Oceanographic Operations covering almost the entire inner continental shelf of the country from the 1960s through the 1980s. Surveys provided geological data on the sea bottom and marine biota along the entire Brazilian coast. This report lists data on 15 hydroid species collected during Operations GEOCOSTA RIO I in 1979 and GEOCOSTA RIO II in 1986, at depths ranging from 25 to $89 \mathrm{~m}$. Hydroids were obtained at two of 65 stations in Operation GEOCOSTA RIO I, each represented by one species: Aglaophenia rhynchocarpa Allman, 1877 and Plumularia strobilophora Billard, 1913. In Operation GEOCOSTA RIO II, hydroids were present at four of the 25 sampled stations. Fourteen species were recorded: Pennaria disticha Goldfuss, 1820, Tubulariidae mt.1, Filifera mt.1, Filifera mt.2, Bougainvilliidae mt.1, Bimeria vestita Wright, 1859, Plumularia strobilophora Billard, 1913, Amphisbetia operculata (Linnaeus, 1758), Dynamena dalmasi (Versluys, 1899), Sertularella tenella (Alder, 1857), Campanularia hincksii Alder, 1856, Clytia gracilis (M. Sars, 1850), Clytia paulensis (Vanhöffen, 1910), and Orthopyxis integra (Macgillivray, 1842). The ranges of three species (Aglaophenia rhynchocarpa, Plumularia strobilophora, Clytia paulensis) were extended southwards along the Brazilian coast. The bathymetric distributions of six species (B. vestita, P. strobilophora, C. hincksii, C. paulensis, D. dalmasi, O. integra) were also extended on the Brazilian continental shelf. Keywords: hydroida, list of species, taxonomy, distribution, marine fauna.
\end{abstract}

GROHMANN, P.A., NOGUEIRA, C.C. \& SILVA, V.M.A.P. Hidróides (Cnidaria, Hydrozoa) coletados na plataforma continental interna do estado do Rio de Janeiro, Brasil, durante as Operações Oceanográficas GEOCOSTA RIO I e II. Biota Neotrop. 11(2): http://www.biotaneotropica.org.br/v11n2/pt/ abstract?article+bn03711022011

Resumo: A marinha brasileira (DHN/MB) promoveu, de 1960 a 1980, uma série de operações oceanográficas, cobrindo quase toda a plataforma continental interna brasileira. As pesquisas forneceram dados geológicos sobre o fundo e a biota marinha ao longo de toda a costa brasileira. Este relato lista dados sobre 15 espécies de hidróides coletadas durante as operações GEOCOSTA RIO I, em 1979 e GEOCOSTA RIO II, em 1986, em profundidades variando de 25 e 89 m. Os hidróides foram obtidos em duas das 65 estações da Operação GEOCOSTA RIO I, cada uma representada por uma especie: Aglaophenia rhynchocarpa Allman, 1877 e Plumularia strobilophora Billard, 1913. Durante a Operação GEOCOSTA RIO II, 14 espécies foram obtidas em quatro das 25 estações: Pennaria disticha Goldfuss, 1820, Tubulariidae mt.1, Filifera mt.1, Filifera mt.2, Bougainvilliidae mt.1, Bimeria vestita Wright, 1859, Plumularia strobilophora Billard, 1913, Amphisbetia operculata (Linnaeus, 1758), Dynamena dalmasi (Versluys, 1899), Sertularella tenella (Alder, 1857), Campanularia hincksii Alder, 1856, Clytia gracilis (M. Sars, 1850), Clytia paulensis (Vanhöffen, 1910), e Orthopyxis integra (Macgillivray, 1842). A distribuição de três espécies (Aglaophenia rhynchocarpa, Plumularia strobilophora, Clytia paulensis) foi ampliada na costa brasileira rumo ao sul. A distribuição batimétrica de seis espécies (B. vestita, P. strobilophora, C. hincksii, C. paulensis, D. dalmasi, O. integra) também foi ampliada na plataforma continental brasileira.

Palavras-chave: hydroida, lista de espécies, taxonomia, distribuição, fauna marinha. 


\section{Introduction}

The first comprehensive studies on hydroids from Brazil were undertaken during the mid-twentieth century by Marta Vannucci, of the Universidade de São Paulo (Vannucci-Mendes 1946, Vannucci 1949, 1950, 195la, b, 1954, 1956). Prior to her work, the only information on the group in the region was based on a few scattered reports by foreign hydroid researchers. These included examinations of material from large oceanic expeditions carried out in the nineteenth and twentieth centuries (e.g. Allman 1888, Nutting $1900,1904)$, or studies of material housed in museums abroad (e.g. Jäderholm 1903, Vervoort 1946). One of the most famous expeditions visiting Brazil was the British Beagle Expedition (1831-1836). Its naturalist, Charles Darwin, first wrote about the arenite reefs of Pernambuco and coral reefs of the northeast coast. The Swedish Eugenie Expedition (1851-1853) collected material at Cabo Frio, Rio de Janeiro. The American Hassler Expedition (1872), led by Louis Agassiz, stopped at Pernambuco for coal and also stayed in Rio de Janeiro. The British Challenger Expedition (1872-1876) collected material along a transect extending from Fernando de Noronha Archipelago to the state of Bahia. The American Albatross Expedition (1887-1888) cruised mainly off the states of Paraíba and Rio de Janeiro. The Scottish National Antarctic Expedition (1902-1904) stopped at São Pedro e São Paulo Archipelago, on the mid-Atlantic ridge $870 \mathrm{~km}$ from the nearest land, and at Fernando de Noronha Archipelago, off Pernambuco state. The British Antarctic Expedition (1910) passed off Rio de Janeiro and Trindade Island.

Specimens of hydroids collected off the Brazilian coast by these expeditions exist in several museums overseas and most important collections are held at the Schwedische Reichsmuseum in Stockholm (Jäderholm 1903), the Rijksmuseum van Natuurlijke Historie in Leiden, and the Zoological Museum in Amsterdam (Vervoort 1946) and the Royal Scottish Museum in Edinburgh (Rees \& Thursfield 1965). Jäderholm (1903) listed a few species collected by the frigate Eugenie [Obelia bidentata Clarke, 1875; Hebella scandens (Bale, $1888)$ = Lafoea cylindrica von Lendenfelt, 1843; Sertularella tenella (Alder, 1856)]. Vervoort (1946) identified several species collected off Caravelas, at Bahia [Idiellana pristis (Lamouroux, 1816) = Idiella pristis (Lamouroux, 1816); Aglaophenia rhynchocarpa Allman, $1877=$ A. rathbuni Nutting, 1900].

A series of oceanographic operations covering almost the entire inner continental shelf of Brazil, commissioned by the Diretoria de Hidrografia e Navegação do Ministério da Marinha (DHN/MM), were carried out from the 1960s through the 1980s. These were designated as NORTE-NORDESTE I (1967), NORTE-NORDESTE II (1968), LESTE II (1969), PLATSUL I (1977), CONVERSUT I (1977), CONVERSUT II (1978), GEOMAR X (1978), GEOCOSTA RIO I (1979) and GEOCOSTA RIO II (1986). Both plankton and benthic communities were sampled, but more reports have appeared on plankton (Nogueira 1977, Hubold \& Gurgel 1977, Hubold 1979, Silva 1979, Abreu \& Nogueira 1989, Bonecker et al. 1993, Dias 1996) because more Brazilian specialists were working on that community at the time. Reports on benthos include studies of Mollusca (Absalão 1986, 1989, Absalão \& Cruz 1990, Gomes \& Absalão 1996). The first study on cnidarians from these cruises appeared as a report of the Operation GEOMAR X, covering the coast from Cabo de São Tomé to southern Bahia, in the area between the $16^{\circ}$ and $22^{\circ}$ south parallels (Grohmann et al. 2003). The present report lists species collected during two other cruises, GEOCOSTA RIO I (1979) and GEOCOSTA RIO II (1986) that explored the State of Rio de Janeiro inner continental shelf.

\section{Material and Methods}

Operation GEOCOSTA RIO I was undertaken in 1979 along the coast of the state of Rio de Janeiro from north of Cape Buzios to near Juatinga Point, south of Angra dos Reis, aboard Oceanographic Vessel Almirante Câmara (Navio Oceanográfico Almirante Câmara) (Figure 1).
A total of 65 bottom stations, extending bathymetrically to the $100 \mathrm{~m}$ isobath, were sampled using a $0.35 \mathrm{~m}^{2}$ van Veen grab. Aboard ship, samples were washed through sieves with $1 \mathrm{~mm}$ mesh. Material was rough-sorted into major groups, fixed in a $10 \%$ formalin solution in seawater, and labeled with the main field data.

Operation GEOCOSTA RIO II covered the coast of Rio de Janeiro, in 1986, from south of Cabo Frio Island to near Araruama County using R/V Suboficial Oliveira (Aviso de Pesquisa Suboficial Oliveira). This area ranges between $22^{\circ} 55^{\prime} \mathrm{S}$; $042^{\circ} 00^{\prime} \mathrm{W}$ and $23^{\circ} 05^{\prime} \mathrm{S} ; 042^{\circ} 20^{\prime} \mathrm{W}$ (Figure 1). Sampling was undertaken at a series of 25 stations, arranged along five transects perpendicular to the coast and located 2.5 to 4 nautical miles from each other. The five transects were termed Transect A (near Figueira Bay, just in front of the mileage beacon), Transect B (off Franceses Island), Transect C (off the Focinho do Cabo, at Cabo Frio Island), Transect D (off Pernambucana Lagoon), and Transect E (between Gaivotas and Tucuns bays) (Alves 1990). The number of stations per transect ranged from three to six, about 1 nautical mile apart from each other. Benthic samples were obtained with a $0.1 \mathrm{~m}^{2}$ van Veen grab weighing $35 \mathrm{~kg}$. A rectangular dredge $(60 \times 50 \times 21 \mathrm{~cm}$, with a metal screen having a $1.5 \mathrm{~cm}$ mesh opening) was also towed for some $3-5$ minutes at each station. Because of the limited length of the cable available, dredge samples were limited to the shallower stations ( 25 to $89 \mathrm{~m}$ ) on each transect (see round marks in Figure 1). The material was washed and processed the same way as the last operation.. Hydroids were present in samples dredged on stations A1, B1 and E1 (Figure 1, Table 1). In the laboratory, hydroids from both operations were mounted on slides [as described by Maÿal (1973), modified by Souza (1987)]. Preserved samples and slides are deposited in the wet and slide collections of the Laboratory of Cnidaria in the Department of Zoology of the Instituto de Biologia da Universidade Federal do Rio de Janeiro (IBUFRJ).

Abiotic data including depth, temperature, and salinity were measured at each station. Depth was obtained by echo sounding and temperature and salinity from water samples taken with a Nansen bottle (Alves, 1990) (see Table 2).

\section{Results}

A total of 15 species were distinguished in samples from GEOCOSTA RIO I and GEOCOSTA RIO II. Their identifications followed various descriptions (Vannucci 1951a, 1954, Millard 1975, Calder 1988, 1990, 1997, Migotto 1996) (Figures 2 and 3).

Class Hydrozoa Owen, 1843

Subclass Hydroidolina Collins, 2000

Order Anthoathecata Cornelius, 1992

Suborder Capitata Kühn, 1913

Family Pennariidae McCrady, 1859

1. Pennaria disticha Goldfuss, 1820

Family Tubulariidae Fleming, 1828

2. Tubulariidae mt. 1

Suborder Filifera Kühn, 1913

3. Filifera mt.1

4. Filifera mt.2

Family Bougainvilliidae Lütken, 1850

5. Bougainvilliidae mt.1

6. Bimeria vestita Wright, 1859a

Order Leptothecatae Cornelius, 1992

Suborder Conica Broch, 1910

Family Aglaopheniidae Marktanner-Turneretscher, 1890

7. Aglaophenia rhynchocarpa Allman, 1877 
Family Plumulariidae Hincks, 1868

8. Plumularia strobilophora Billard, 1913

Family Sertulariidae Lamoroux, 1812

9. Amphisbetia operculata (Linnaeus, 1758)

10. Dynamena dalmasi (Versluys, 1899)

11. Sertularella tenella (Alder, 1857)

Suborder Proboscoida Broch, 1910

Family Campanulariidae Johnston, 1837

12. Campanularia hincksii Alder, 1856

13. Clytia gracilis (M. Sars, 1850)

14. Clytia paulensis (Vanhöffen, 1910)

15. Orthopyxis integra (Macgillivray, 1842)

The unidentified species are characterized as the following diagnosis:

Tubulariidae $\mathrm{mt} 1$ :

Colonies formed by unbranched stems bearing single terminal hydranths. Erect slightly annulated hydrocauli, with firm perisarc.
Hydranths provided with oral and aboral filiform tentacles. Gonophores present just above aboral tentacles, with medusa-buds.

Filifera mt 1:

Colony formed by erect hydrocauli, annulated at base. Stems annulated at base arising from the hydrocauli alternatively. Hydranth provided with a circle of filiform tentacles around the hypostome. Perisarc extending the tentacles base slightly (pseudohydrotheca?).

Filifera mt.2:

Stolonal colony with stems arising from hydrorhiza; hydranth provided with a circle of filiform tentacles around the hypostome. Perisarc slightly investing the lower part of the hydranth body (pseudohydrotheca?).

Bougainvilliidae mt.1

Colony with erect annulated hydrocauli and smooth apophysis stem. Annulated stems alternately arising from apophysis in the hydrocauli. Hydranths provided with a circle of filiform tentacles around the hypostome. Perisarc slightly investing the lower part of the hydranth body (pseudohydrotheca?).
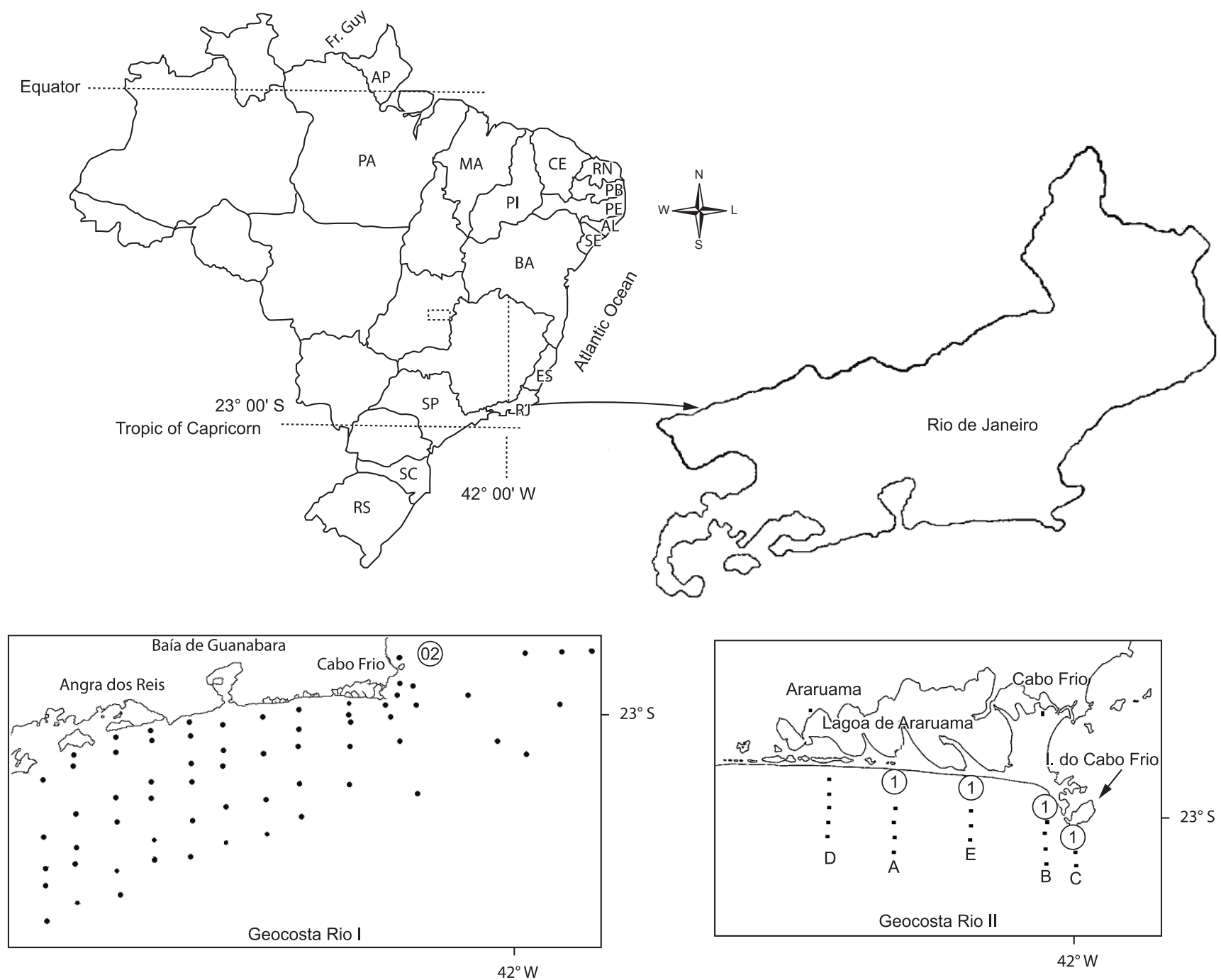

Figure 1. Map showing the collecting areas, along the Brazilian coast, of the two Oceanographic Operations: Study Area 1 - Operation GEOCOSTA RIO I; Study Area 2 - Operation GEOCOSTA RIO II. Round marks = stations presenting hydroids. 
Grohmann, P.A. et al.

Table 1. Species per site of collection in GCR I and GCR II (= Operations GEOCOSTA RIO I and GEOCOSTA RIO II).

\begin{tabular}{|c|c|c|c|c|c|c|c|c|}
\hline \multirow[t]{2}{*}{ Species } & \multicolumn{2}{|c|}{ GCR I } & \multicolumn{4}{|c|}{ GCR II } & \multirow[t]{2}{*}{ Foc $(\%)$} & \multirow[t]{2}{*}{ Distrib. along the Brazilian coast } \\
\hline & \#unkn & $\# 2$ & \#A1 & \#B1 & \#C1 & \#E1 & & \\
\hline Pennaria disticha & 0 & 0 & 0 & $\mathrm{X}$ & 0 & $\mathrm{X}$ & 50,0 & CE, FN, PE, BA, ES, RJ, SP, PR, SC \\
\hline Tubulariidae mt 1 & 0 & 0 & $\mathrm{X}$ & $\mathrm{X}$ & 0 & $\mathbf{X}^{*}$ & 75,0 & - \\
\hline Filifera mt 1 & 0 & 0 & $X$ & 0 & 0 & 0 & 25,0 & - \\
\hline Filifera mt 2 & 0 & 0 & 0 & 0 & $\mathrm{X}$ & 0 & 25,0 & - \\
\hline Bougainvilliidae mt 1 & 0 & 0 & $\mathrm{X}$ & 0 & 0 & $\mathrm{X}$ & 50,0 & - \\
\hline Bimeria vestita & 0 & 0 & 0 & $\mathbf{X}^{*}$ & 0 & 0 & 25,0 & CE, BA, ES, RJ, SP \\
\hline Aglaophenia rhynchocarpa & $\mathrm{X}$ & 0 & 0 & 0 & 0 & 0 & 25,0 & BA, RJ \\
\hline Plumularia strobilophora & 0 & $\mathrm{X}$ & 0 & $\mathrm{X}$ & 0 & 0 & 25,0 & ES, RJ \\
\hline Amphisbetia operculata & 0 & 0 & 0 & $\mathrm{X}$ & 0 & 0 & 25,0 & RJ \\
\hline Dynamena dalmasi & 0 & 0 & 0 & $\mathrm{X}$ & 0 & 0 & 25,0 & BA, RJ, SP \\
\hline Sertularella tenella & 0 & 0 & 0 & $\mathrm{X}$ & $\mathrm{X}$ & 0 & 50,0 & BA, RJ \\
\hline Campanularia hincksii & 0 & 0 & 0 & $\mathrm{X}$ & $\mathrm{X}$ & 0 & 50,0 & BA, RJ \\
\hline Clytia gracilis & 0 & 0 & 0 & $\mathrm{X}$ & 0 & 0 & 25,0 & PE, BA, RJ, SP \\
\hline Clytia paulensis & 0 & 0 & 0 & $\mathbf{X}^{*}$ & $\mathrm{X}$ & 0 & 50,0 & PE, ES, RJ \\
\hline Orthopyxis integra & 0 & 0 & 0 & $\mathbf{X}^{*}$ & 0 & 0 & 25,0 & RJ, PR \\
\hline Total & 1 & 1 & 3 & 11 & 4 & 3 & - & - \\
\hline
\end{tabular}

$\#=$ station of collection; $0=$ absent $\mathrm{X}=$ present $; \mathrm{X}^{*}=$ present and fertile; Foc $=$ frequency of occurrence. Distrib. $=$ distribution; $\mathrm{mt}=\mathrm{morphotype}$. $\mathrm{CE}=$ Ceará; FN = Fernando de Noronha Archipelago (PE); PE = Pernambuco; BA = Bahia; ES = Espírito Santo; RJ = Rio de Janeiro; $\mathrm{SP}=\mathrm{São}$ Paulo; $\mathrm{PR}=$ Paraná; $\mathrm{SC}=$ Santa Catarina. The extended distributions are indicated in bold face.

Table 2. Data relative to operations Geocosta Rio I and Geocosta Rio II.

\begin{tabular}{|c|c|c|c|c|c|c|c|c|c|}
\hline Oper & sta & Date & Coords & $\begin{array}{l}\text { Depth } \\
\text { (m) }\end{array}$ & $\begin{array}{c}\text { Depth } \\
\text { Secchi }(m)\end{array}$ & $\mathbf{T}^{\circ} \mathbf{C}$ & $\begin{array}{c}\text { Wc } \\
\text { IBUFRJ }\end{array}$ & $\begin{array}{c}\text { Sc } \\
\text { IBUFRJ }\end{array}$ & Substrate \\
\hline \multirow[t]{2}{*}{ GCR I } & $? 01$ & $31 / 07 / 79$ & - & - & - & - & $\begin{array}{l}0-267 \\
0-268\end{array}$ & $0-657$ & - \\
\hline & 02 & $31 / 07 / 79$ & $22^{\circ} 41^{\prime} \mathrm{S} ; 41^{\circ} 43,5 \mathrm{~W}$ & 50 & $?$ & 21,4 & $0-269$ & $0-656$ & mud + gravel \\
\hline \multirow[t]{4}{*}{ GCR II } & A1 & $\begin{array}{c}\text { 08/05/86 } \\
\text { dredge }\end{array}$ & $22^{\circ} 57^{\prime} 35 \mathrm{~S} ; 42^{\circ} 13^{\prime} 94 \mathrm{~W}$ & 29 & 9 & 20 & $0-504$ & $\begin{array}{c}0-576 \\
0-1106 \\
0-1107\end{array}$ & medium sand \\
\hline & B1 & $\begin{array}{c}\text { 24/03/86 } \\
\text { dredge }\end{array}$ & $22^{\circ} 59^{\prime} 17 \mathrm{~S} ; 42^{\circ} 02^{\prime} 34 \mathrm{~W}$ & 35 & 11 & 19 & $\begin{array}{c}0-497 \\
0-502 \\
0-503 \\
0-1108 \text { to } 0-1116\end{array}$ & $\begin{array}{l}0-577 \\
0-578\end{array}$ & $\begin{array}{l}\text { medium to } \\
\text { fine sand }\end{array}$ \\
\hline & $\mathrm{C} 1$ & $24 / 03 / 86$ & $23^{\circ} 01^{\prime} 20 \mathrm{~S} ; 42^{\circ} 00^{\prime} 00 \mathrm{~W}$ & 89 & 16 & 22,8 & $\begin{array}{l}0-496 \\
0-507 \\
0-508\end{array}$ & $\begin{array}{c}0-579 \\
0-580 \\
0-1117 \\
0-1118\end{array}$ & sandy mud \\
\hline & E1 & $\begin{array}{c}\text { 26/03/86 } \\
\text { dredge }\end{array}$ & $22^{\circ} 57^{\prime} 05 \mathrm{~S} ; 42^{\circ} 00^{\prime} 00 \mathrm{~W}$ & 25 & 8 & 18 & $\begin{array}{l}0-498 \\
0-501\end{array}$ & $0-581$ to $0-583$ & medium sand \\
\hline
\end{tabular}

Oper = Operation, sta = stations, coords =geographic coordinates, $\mathrm{T}^{\circ} \mathrm{C}=$ temperature on the Celsius scale, $\mathrm{S}=$ salinity; $\mathrm{Wc} I B U F R J-\mathrm{n}=$ wet collection of Instituto de Biologia da Universidade Federal do Rio de Janeiro-catalog number; Sc IBUFRJ-n = slide collection of Instituto de Biologia da Universidade Federal do Rio de Janeiro-catalog number.

\section{Hydroids collected during Operation GEOCOSTA RIO I}

Hydroids were present at two of the 65 stations $(3.1 \%)$, each with a single species. Aglaophenia rhynchocarpa was collected at an unidentified station (\#unkn), as the label was damaged and unreadable. The other species, Plumularia strobilophora, was obtained at station 2 (\#2). The known depth range of this species was extended to $50 \mathrm{~m}$. Both stations were sampled on 31/07/79. Table 1 shows the characterization data of the two stations where hydroids were present (\#unknown and \#2) and their distribution along the Brazilian coast. Salinity measured in \#2 was 36.01 .

\section{Hydroids collected during Operation GEOCOSTA RIO II}

Four $(16 \%)$ of the 25 stations sampled during this operation yielded hydroids, totaling 14 species: Pennaria disticha, Tubulariidae mt.1, Filifera mt.1, Filifera mt.2, Bougainvilliidae mt.1, Bimeria vestita, Plumularia strobilophora, Amphisbetia operculata, Dynamena dalmasi, Sertularella tenella, Campanularia hincksii, Clytia gracilis, Clytia paulensis, and Orthopyxis integra. The most frequent of these was Tubulariidae mt.1 (75\%). Four of the species were fertile (Tubulariidae mt.1, B. vestita, C. paulensis, O. integra) (see Table 1). Also depth ranges of five species were extended: 

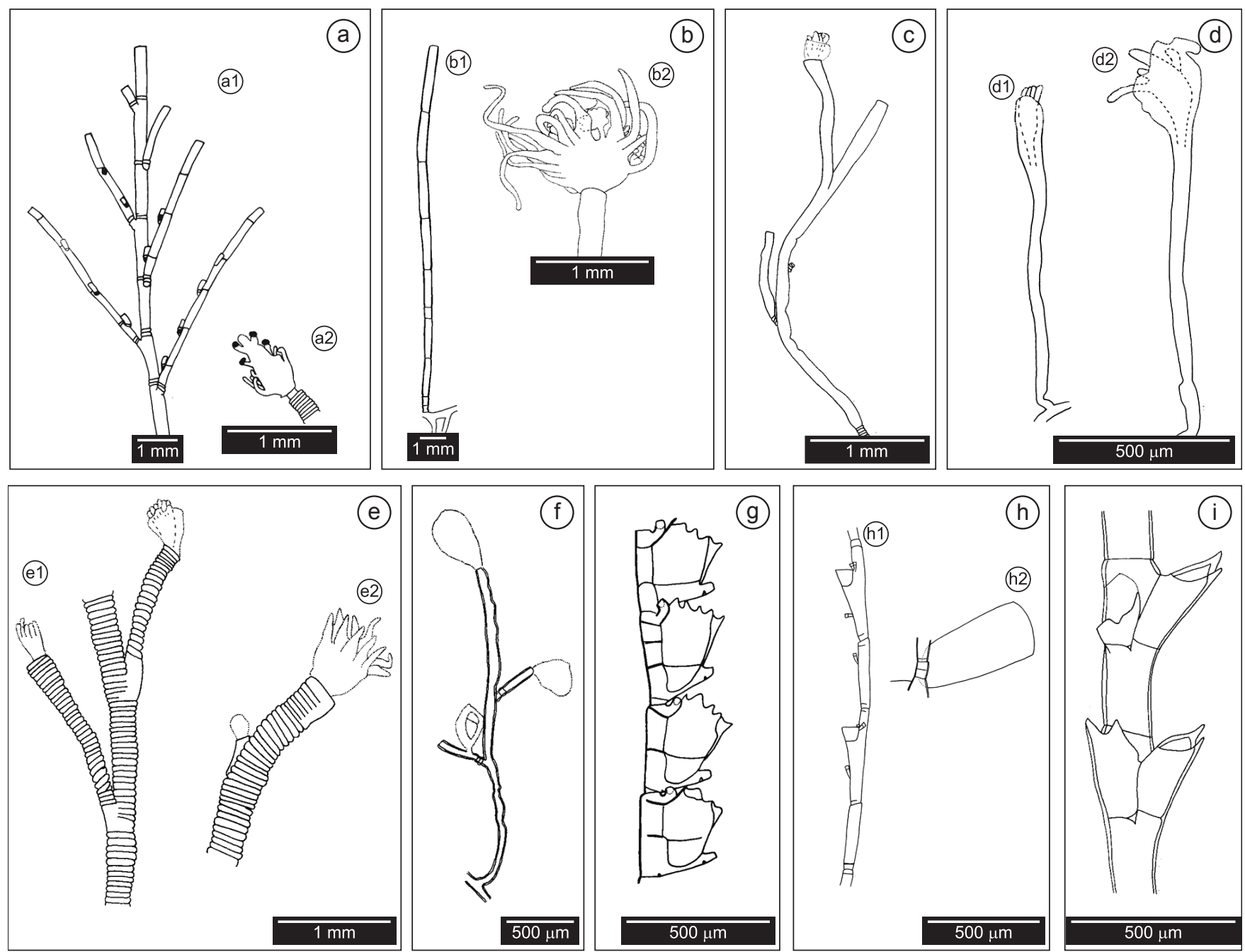

Figure 2. a) Pennaria disticha Goldfuss, 1820: a1-colony bearing hydrocaulus and hydrocladia; a2-peduncle and hydranth. Bar = $1 \mathrm{~mm}$; b) Tubulariidae mt.1: b1-colony bearing hydrorhiza and hydrocaulus; b2-hydrocaulus and hydranth with gonophores between the two whorls of tentacles. Bar = $1 \mathrm{~mm}$; c) Filifera mt.1: colony bearing hydrocaulus, peduncles and hydranths (with pseudohydrotheca?). Bar $=1 \mathrm{~mm}$; ) Filifera mt.2: d1-colony bearing stolon, peduncle and hydranth (with pseudohydrotheca?); d2-colony with peduncle and hydranth (with pseudohydrotheca?). Bar = 500 $\mu$ m; e) Bougainvillia mt.1: e1-colony bearing hydrocaulus, peduncles and hydranths (with pseudohydrotheca?); e2-peduncle and hydranth without pseudohydrotheca. Bar = $1 \mathrm{~mm}$; f) Bimeria vestita Wright, 1859: colony bearing hydrorhiza, hydrocaulus, peduncles, hydranths and gonophore. Bar $=500 \mu \mathrm{m} ; \mathrm{g}$ ) Aglaophenia rhynchocarpa Allman, 1877: colony bearing hydrocladia, internodes, hydrothecae and nematothecae. Bar $=500 \mu \mathrm{m} ; \mathrm{h})$ Plumularia strobilophora Billard, 1913: h1-colony bearing hydrocladia, internodes, hydrothecae and nematothecae; h2-gonotheca and parts of the hydrocaulus and hydrocladia. Bar $=500 \mu$ m; i) Amphisbetia operculata (Linnaeus, 1758): colony bearing hydrocaulus, internodes and hydrothecae. Bar $=500 \mu \mathrm{m}$.

B. vestita, D. dalmasi and $O$. integra to $35 \mathrm{~m}$, and $C$. hincksii and C. paulensis to $89 \mathrm{~m}$ (Table 2). Geographic ranges of three species were extended southwards, along the Brazilian coast, considering both operations: A. rhynchocarpa and P. strobilophora, collected during GEOCOSTA RIO I (Table 1), and $C$. paulensis, collected during GEOCOSTA RIO II. Table 1 shows the characterization data of the stations where hydroids were present and the species distribution along the Brazilian coast. Salinity was the only abiotic factor that almost did not change along the stations. It was higher in \#E1 (36.95) and lower in \#C1 (36.16).

\section{Discussion}

\section{Distribution}

\subsection{Operation GEOCOSTA RIO I}

Aglaophenia rhynchocarpa, obtained at an unknown station (probably \#1), had been found previously in Brazil only off Caravelas, on the coast of Bahia. Nutting (1900) stated that the specimen housed at the United States National Museum was collected by 

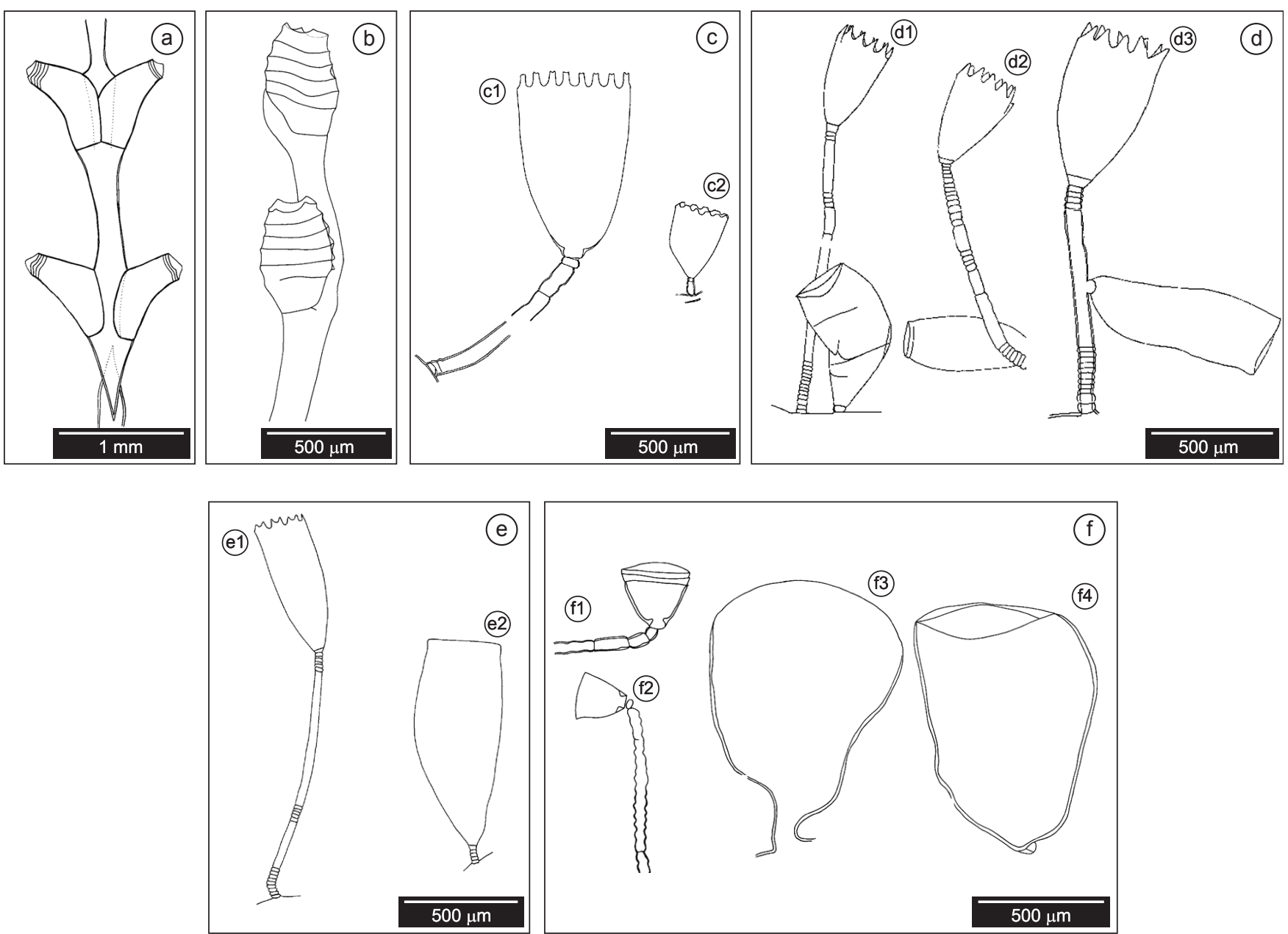

Figure 3. a) Dynamena dalmasi (Versluys, 1899): colony bearing hydrocaulus, internodes and hydrothecae. Bar $=500 \mu \mathrm{m}$; b) Sertularella tenella $($ Alder, 1856): part of a colony bearing hydrocaulus and hydrothecae. $B a r=500 \mu \mathrm{m} ; \mathrm{c}$ ) Campanularia hincksii Alder, 1856: $\mathrm{c} 1$ and $\mathrm{c} 2$-pieces of colony bearing stolon, peduncle and hydrotheca. Bar $=500 \mu \mathrm{m}$; d) Clytia gracilis (M. Sars, 1850): d1, d2 and d3-pieces of colonies bearing stolon, peduncle, hydrotheca and gonotheca. $\mathrm{Bar}=500 \mu \mathrm{m}$; e) Clytia paulensis (Vanhöffen, 1910): e1-colony bearing stolon, peduncle and hydrotheca; e2-stolon and gonotheca. Bar $=500 \mu \mathrm{m} ; \mathrm{f})$ Orthopyxis integra (MacGillivray, 1842): f1-colony bearing peduncle and hydrotheca; f2-stolon, peduncle and hydrotheca; $\mathrm{f} 3$ and $\mathrm{f} 4$-gonothecae. Bar $=500 \mu \mathrm{m}$.

Richard Rathbun in 1876. Later, colonies of the same species from the Zoological Museum at Amsterdam and labeled as having been collected by Kroon on 10 March 1896 were reported by Vervoort (1946). During his studies of the hydroids housed in the ZMA, Vervoort identified the species as A. rathbuni, but in a later paper (Vervoort 1959) assigned it to the synonymy of A. latecarinata Allman. Recently, A. rathbuni was considered a synonym of A. rhynchocarpa Allman, 1877 (Calder 1997). The species, believed by Vervoort (1946) to be limited in distribution, has not otherwise been reported in the literature from Brazil. Its discovery off the state of Rio de Janeiro, at a GEOCOSTA RIO I station, suggests that it is merely uncommon. Plumularia strobilophora, collected at station 2 (\#2), had previously been found in Brazil only at Trindade Island, state of Espírito Santo (Vannucci 1951a) (Table 1).

\subsection{Operation GEOCOSTA RIO II}

Pennaria disticha has recently been reported from Ceará (Shimabukuro et al. 2006), Pernambuco, in the Fernando de
Noronha Archipelago (Eston et al. 1986, Pires et al. 1992) and near Tamandaré (Calder \& Maÿal 1998), as well as from Bahia (Kelmo \& Santa-Isabel 1998, Grohmann et al. 2003), Espírito Santo (Vannucci 1951b, Souza 1987, Grohmann et al. 1997), Rio de Janeiro (Vannucci 1950, 1951a) São Paulo (Vannucci 1954, Migotto \& Silveira 1987, Silveira \& Migotto 1991, Migotto 1996, Rosso \& Marques 1997, Marques \& Migotto 2004), Paraná (Vannucci 1954, Migotto 1996) and Santa Catarina (Silveira \& Migotto 1991). Bimeria vestita is known from Ceará (Shimabukuro et al. 2006), Bahia (Kelmo \& Santa-Isabel 1998), Espírito Santo (Grohmann et al. 1997), and São Paulo (Migotto 1996, Rosso \& Marques 1997, Marques \& Migotto 2004). As noted above, Plumularia strobilophora has been previously reported only at Trindade Island, state of Espírito Santo (Vannucci 1951a). Amphisbetia operculata has been recorded earlier only from Rio de Janeiro (Vannucci 1954, Grohmann et al. 2008). This species is probably limited in distribution or even uncommon, since it has not otherwise been reported in Brazil. Dynamena dalmasi was previously found in Bahia (Ritchie 1909, Grohmann et al. 2003) and São Paulo (Migotto 1996). Sertularella tenella, reported from 
Bahia by Grohmann et al. (2003), was first collected in Brazil in Cabo Frio, Rio de Janeiro, during the Eugenie Expedition (Jäderholm 1903). Campanularia hincksii was recently reported for Bahia by Grohmann et al. (2003), although it was first collected by Vannucci (1954) in Rio de Janeiro as Campanularia hesperia. Clytia gracilis has been found in Pernambuco (Calder \& Maÿal 1998), Bahia (Grohmann et al. 2003) and São Paulo (Migotto 1996, Migotto et al. 2001). Clytia paulensis has still been obtained in Pernambuco (Calder \& Maÿal 1998) and Espírito Santo (Grohmann et al. 1997). Finally, Orthopyxis integra has been reported from Rio de Janeiro [Vannucci (1949) as O. minuta sp. nov.] and Paraná (Haddad 1992) (Table 2).

\section{Sistematics}

Hydroids in general are composed of very delicate material, mainly the anthoathecatae, so that they are easily damaged when collected with heavy equipment such as grabs and dredges. Sometimes, they can hardly be identified because of this. On the other hand, it is not always possible to be sure about a species because of the lack of data about its biological cycle.

Concerning the Tubulariidae mt.1, the specimens observed resemble both Ectopleura dumortieri (van Beneden, 1844) and Pinauay ralphi (Bale, 1884). As differential characters, Migotto \& Silveira (1987) mentioned the presence of four endodermic canals on the hydrocauli of the polyps and the production of medusoids in E. dumortieri and the lack of these canals and the production of cryptomedusoids in $P$. ralphi. As these endodermic canals were not seen on the examined material, the species is assumed to be $P$. ralphi.

Filifera mt.1 and Filifera mt.2 show characteristics assigned to different genera of different families of Filifera, so that the identification of these morphotypes is solely speculative. Filifera mt.1 seems much like Leuckartiara octona (Fleming, 1823), but the material was too damaged to be certain; so few specimens of Filifera $\mathrm{mt} .2$ were available that identification was also impossible.

With regard to the Bougainvilliidae mt.1, Migotto et al. (2002) reported six genera of Bougainvilliidae for Brazil: Bimeria Wright, 1859; Garveia Wright, 1859; Bougainvillia Lesson, 1830; Parawrightia Warren, 1907; Rhizorhagium M. Sars, 1877; and Thamnostoma Haeckel, 1879. They noted that Bougainvillia is the most common hydrozoan genus in Brazil, but almost all its species have been recorded as medusae, namely B. carolinensis (McCrady, 1859); B. frondosa Mayer, 1900; B. muscus (Allman, 1863); B. niobe Mayer, 1894; B. platygaster (Haeckel, 1879); and B. trinema (von Lendenfeld, 1884). Until the early 1990s, only B. rugosa Clarke, 1882 had been reported in both hydroid and medusa stages. Then, working on hydroid stages, Haddad (1992) identified B. muscus [=Bougainvillia ramosa $($ van Beneden, 1844)] in Paraná. The colonies reported here as Bougainvilliidae mt.1 have an annulated perisarc, and occasionally a pseudohydrotheca can be seen around the hydranths. Another marked characteristic is the presence of tiny smooth regions at the apophysis of the hydranths (see Plate 1). Vannucci \& Rees (1961) stated that environmental factors could greatly influence the appearance of the Bougainvillia species, so that sometimes they differ little from each other. The same opinion was shared by Calder (1988) in his study of shallow-water Athecatae hydroids of Bermuda. According to the general morphological characters, the closed species to this morphotype is Perigonimus robustus Fraser, 1938; nevertheless, this species possesses undulated pseudohydrothecae and their hydrocauli are deprived of smooth regions. Millard (1975) recorded Bougainvillia muscus [(=Bougainvillia ?ramosa (van Beneden, 1844)] from South Africa, and her drawing also looks somewhat like this species. However, because they were sterile these hydroids could not be identified to genus and further study is needed to establish their identity.
According to Nishihira (1969), while some hydroid species are indifferent to substratum, others are highly exigent. The number of species found during this work was probably limited by the nature of the substrate in both study areas. Sand (sometimes with shell gravel) and/or mud predominated, providing unfavorable conditions for settlement of the larval stages of numerous species. Earlier authors, such as Werner (1963), stated that in hydroids the first attachment to the substratum is effected by means of the adhesive effect of the nematocysts of their larvae, thus enlarging the area of contact. Probably for this reason, with the exception of the interstitial species, hydroids are infrequent on mud or sand. Although many species are substrate generalists, they are most prevalent on consolidated bottoms, as epilithic forms (e.g. Henry \& Kenchington 2004), in the phytal, as epiphytic forms (e.g. Nishihira 1969, Boero \& Fresi 1985, Oliveira $\&$ Marques 2007) and/or attached on other animals as epizoic forms (e.g. Piraino et al. 1992, Boero \& Hewitt 1992, Henry \& Kenchington 2004). Hydroids were also most diverse and abundant during this study at stations nearest the coast. According to Millard (1978), shallow waters constitute the optimum zone for hydroids.

\section{Acknowledgements}

Our special thanks are due to our colleagues Dale R. Calder of the Department of Natural History, Royal Ontario Museum, Canada and Tito Lotufo of the Instituto de Ciências do Mar - LABOMAR, Universidade Federal do Ceará, for revising and improving the manuscript; Janet W. Reid, research associate with the Virginia Museum of Natural History, USA, for the first English version. Thanks are also due to the two anonymous reviewers for suggestions and to Orane F. S. Alves of the Departamento de Zoologia, Instituto de Biologia, Universidade Federal da Bahia, for permitting the use of data from her unpublished thesis. To the Diretoria de Hidrografia e Navegação da Marinha do Brasil (DHN-MB) for the opportunity to sail on its oceanographic vessels from the 1960s to the 1980 s

\section{References}

ABREU, P.C.O.V. \& NOGUEIRA, C.R. 1989. Spatial distribution of Siphonophora species at Rio de Janeiro coast, Brazil. Ciên. Cult. 41(9):897-902.

ABSALÃO, R.S. 1986. Moluscos da comissão oceanográfica GEOCOSTARIO I, RJ, Brasil. Rev. Brasil. Biol. 46(1):27-31.

ABSALÃO, R.S. 1989. Padrões distributivos e zoogeografia dos moluscos da plataforma continental brasileira. Parte III Comissão Oceanográfica ESPÍRITO SANTO. Mem. Inst. Oswaldo Cruz. 84 (Supl. IV):1-6.

ABSALÃO, R.S. \& CRUZ, R.L.S. 1990. Moluscos da plataforma continental brasileira. Parte II. Comissão Oceanográfica GEOMAR X. Naturalia. 15:21-33.

ALLMAN, G.J. 1888. Report on the Hydroida dredged by H.M.S. Challenger during the years 1873-76. Part II - The Tubularinae, Corymorphinae, Campanularinae, Sertularinae and Thalamophora. Report on the Scientific Results of the Voyage of the H.M.S. Challenger during the years 187376. Zoology. 23(70):1-90.

ALVES, O.F.S. 1990. Associações de moluscos e Echinodermos da plataforma continental interna entre Cabo Frio e Saquarema (RJ) e suas características ambientais. Dissertação de Mestrado, Instituto de Geociências, Universidade Federal do Rio de Janeiro, Rio de Janeiro.

BOERO, F. \& FRESI, E. 1986. Zonation and evolution of a rocky bottom hydroid community. PSZN I: Mar. Ecol. 7(2):123-150. http://dx.doi. org/10.1111/j.1439-0485.1986.tb00152.x

BOERO, F. \& HEWITT, C. 1992. A hydrozoan, Zanclella bryozoophila n.gen., n.sp. (Zancleidae) symbiotic with a bryozoan, with a discussion of the Zancleoidea. Can. J. Zool. 70:1645-1651. http://dx.doi.org/10.1139/ z92-229 
BONECKER, S.L.C.; NOGUEIRA, C.R.; BONECKER, A.C.T.; SANTOS, L.H.S.; REYNIER, M.V. \& TENENBAUM, D.R. 1993. Estudo hidrográfico e planctonológico da região entre Cabo Frio (Rio de Janeiro) e o Arquipélago de Abrolhos (Bahia) - Brasil. Nerítica 7(1-2):71-86.

CALDER, D.R. 1988. Shallow-water hydroids of Bermuda- The Athecate. Life Sci. Contrs Roy. Ontario Mus. 148:1-107.

CALDER, D.R. 1990. Shallow-water hydroids of Bermuda-The Thecatae, exclusive of Plumularioidea. Life Sci. Contrs Roy. Ontario Mus. 154:1-140.

CALDER, D.R. 1997. Shallow-water Hydroids of Bermuda: The Thecatae (Superfamily Plumularioidea). Life Sci. Contrs Roy. Ontario Mus. 161:1-85.

CALDER, D.R. \& MAŸAL, E.M. 1998. Dry season distribution of hydroids in a small tropical estuary, Pernambuco, Brazil. Zool. Verh. 323:69-78.

DIAS, C.O. 1996. Copépodes da costa leste do Brasil. Arq. biol. tecnol. 39(1):113-122.

ESTON, V.R., MIGOTTO, A.E., OLIVEIRA FILHO, E.C., RODRIGUES, S.A. \& FREITAS, J.C. 1986. Vertical distribution of benthic marine organisms on rocky coasts of Fernando de Noronha Archipelago (Brazil). Bolm Inst. Oceanogr. S. Paulo 34:37-53.

GOMES, R.S. \& ABSALÃO, R.S. 1996. Os Caecidae (Mollusca, Prosobranchia, Mesogastropoda) da Operação Oceanográfica GEOMAR XII. Rev. Bras. Zool. 13(2):513-531. http://dx.doi.org/10.1590/S010181751996000200019

GROHMANN, P.A., MORANDINI, A.C. \& MARQUES, A.C. 2008. Medusozoa (Cnidaria) do Norte Fluminense. I. Macaé, RJ. In XXVII Congresso Brasileiro de Zoologia. Sociedade Brasileira de Zoologia, Curitiba. Abstract P-1066. www.cbz2008.com.br

GROHMANN, P.A., NOGUEIRA, C.C., \& SILVA, V.M.A.P. 2003. Hydroids (Cnidaria, Hydrozoa) collected on the continental shelf of Brazil during the GEOMAR X Oceanographic Operation. Zootaxa 299:1-19.

GROHMANN, P.A., SOUZA, M.M. \& NOGUEIRA, C.C. 1997. Hydroids from the vicinity of a large industrial area in Vitória, Espírito Santo, Brazil. In Proceedings of the VI International Conference on Colenterate Biology (J.C. den Hartog, ed.). National Natuurhistorische Museum, Leiden, p.227-232.

HADDAD, M.A. 1992. Hidróides (Cnidaria, Hydrozoa) de costões rochosos do litoral sul do estado do Paraná. 121p. Tese de dissertação, Instituto de Biociências, Universidade de São Paulo, São Paulo.

HENRY, L-A. \& KENCHINGTON, E. 2004. Differences between epilithic and epizoic hydroid assemblages from commercial scallop ground in Bay of Fundy, northwest Atlantic. Mar. Ecol. Progr. Ser. 266:123-134. http:// dx.doi.org/10.3354/meps266123

HUBOLD, G. 1979. Considerações metodológicas sobre a coleta de plâncton realizada durante as operações CONVERSUT I e II (1977-1978). Anais Hidrog. 36:23p.

HUBOLD, G. \& GURGEL, I.M. 1977. Plankton volumes, temperature, and salinity distribution off Rio de Janeiro: preliminary results of the cruise “Operação RIO DE JANEIRO I. 06/06-17/06/1977”. Instituto de Pesquisas da Marinha, Rio de Janeiro, v.131, p.1-9.

JÄDERHOLM, E. 1903. Aussereuropäische Hydroiden im Schwedischen Reichsmuseum. Ark. Zool. 1:259-312.

KELMO, F. \& SANTA-ISABEL, L.M. 1998. The athecate hydroids (Cnidaria, Hydrozoa) from Northern Bahia, Brazil. Rev. Biol. Trop. 46(supl. 5):61-72.

MARQUES, A.C. \& MIGOTTO, A.E. 2004. Hidrozoários (Cnidaria) marinhos bentônicos da Estação Ecológica Juréia-Itatins. In Ambiente, Flora e Fauna da Estação Ecológica Juréia-Itatins (O.A.V. Marques \& W. Duleba, eds.). Holos, Ribeirão Preto, p.170-176.

MAŸAL, E.M. 1973. Hidróides (Hydrozoa, Hydroida) de Pernambuco. Dissertação de mestrado, Instituto de Biociências, Universidade de São Paulo, São Paulo.

MIGOTTO, A.E. 1996. Benthic shallow-water hydroids (Cnidaria, Hydrozoa) of the coast of São Sebastião, Brazil, including a checklist of Brazilian hydroids. Zool. Verh. 306:125p.
MigotTo, A.E., MARQUES, A.C. \& FLYNN, M.N. 2001. Seasonal recruitment of hydroids (Cnidaria) on experimental panels in the São Sebastião Channel, Southeastern Brazil. Bull. Mar. Sci. 68(2):287-298.

MIGOTTO, A.E., MARQUES, A.C., MORANDINI, A.C. \& SILVEIRA, F.L. 2002. Checklist of the Cnidaria Medusozoa of Brazil. Biota Neotrop. 2(1):1-35

MIGOTTO, A.E. \& SILVEIRA, F.L. 1987. Hidróides (Cnidaria, Hydrozoa) do litoral sudeste e sul do Brasil. Halocordylidae, Tubulariidae e Corymorphidae. Iheringia, Sér. Zool. 66:95-115.

MILLARD, N.A.H. 1975. Monograph of the Hydroida of Southern Africa. Ann. S. Afr. Mus. 68:1-513.

MILLARD, N.A.H. 1978. The geographical distribution of Southern African hydroids. Ann. S. Afr. Mus. 74(6):159-200.

NISHIHIRA, M. 1969. Ecological studies of epiphytic Hydrozoa. Bull. Mar. Biol. Stat. Asamushi. 13(3):183-186.

NOGUEIRA, C.S.R. 1977. Estudo de uma coleção de Siphonophora Calycophorae da região Norte-Nordeste do Brasil. Dissertação de mestrado, Universidade Federal do Rio de Janeiro, Rio de Janeiro.

NUTTING, C.C. 1900. American Hydroids. Part I. The Plumularidae. Spec. Bull. U.S. natn. Mus. 4 (1):1-285.

NUTTING, C.C. 1904. American Hydroids. Part II. The Sertularidae. Spec. Bull. U.S. natn. Mus. 4 (2):1-151.

OLIVEIRA, O.M.P. \& MARQUES, A.C. 2007. Epiphytic hydroids (Hydrozoa, Anthoathecata and Leptothecata) of the world. Check List 3(1):21-38.

PIRAINO, S., BOUILLON, J. \& BOERO, F. 1992. Halocoryne epizoica (Cnidaria, Hydrozoa) a hydroid that bites. Sci. Mar. 56(2-3):141-147.

PIRES, D.O., CASTRO, C.B., MIGOTTO, A.E. \& MARQUES, A.C. 1992. Cnidários bentônicos do Arquipélago de Fernando de Noronha, Brasil. Bolm Mus. Nac. Rio de Janeiro, Zool. 354:1-21.

REES, W.J. \& THURSFIELD, S. 1965. The hydroid collections of James Ritchie. Proc. R. Soc. Edinb. (B) 69:34-220.

RITCHIE, J. 1909. Supplementary report on the hydroids of the Scottish National Antarctic Expedition. Trans. R. Soc. Edinb. 47:65-101.

ROSSO, S. \& MARQUES, A.C. 1997. Is there any conspicuous geographical pattern in intertidal hydrozoan distribution along the coast of São Paulo State, Southeastern Brazil? In VI International Conference on Coelenterate Biology. Leiden, The Netherlands, p.415-422.

SHIMABUKURO, V., MARQUES, A.C. \& MIGOTTO, A.E. 2006. Fauna de hidrozoários atecados (Hydrozoa, Anthoathecata) da costa do Estado do Ceará, Brasil. Biota Neotrop. 6(3):1-13.

SILVA, V.M.A.P. 1979. Mysidacea (Crustacea) da costa brasileira. IOperação Norte-Nordeste I. Avulsos Depto Zool. 32:1-18.

SILVEIRA, F.L. DA \& MIGOTTO, A.E. 1991. The variation of Halocordyle disticha (Cnidaria, Athecata) from the Brazilian coast: an environmental indicator species? Hydrobiologia. 216/217:422-437.

SOUZA, M.M. 1987. Levantamento preliminar dos Hydroida (Cnidaria, Hydrozoa) do litoral do estado do Espírito Santo e considerações sobre sua biologia e ecologia. Monogradia de Bacharelado. Universidade Federal do Rio de Janeiro, Rio de Janeiro.

VANNUCCI, M. 1949. Hydrozoa do Brasil. Bolm Fac. Filos. Ciênc. Univ. S. Paulo (Zool.) 99(14):219-265.

VANNUCCI, M. 1950. Resultados científicos do cruzeiro do "Baependi" e do "Vega" à Ilha da Trindade. Hydrozoa. Bolm Inst. Paulista Oceanogr. 1(1):81-96.

VANNUCCI, M. 1951a. Hydrozoa e Scyphozoa existentes no Instituto Paulista de Oceanografia I. Bolm Inst. Paulista Oceanogr. 2(1):69-104.

VANNUCCI, M. 1951b. Distribuição dos Hydrozoa até agora conhecidos nas costas do Brasil. Bolm Inst. Paulista Oceanogr. 2(1):105-124.

VANNUCCI, M. 1954. Hydrozoa e Scyphozoa existentes no Instituto Oceanográfico II. Bolm Inst. Oceanogr., S. Paulo 5(1-2):95-149.

VANNUCCI, M. 1956. Biological notes and description of a new species of Dipurena (Hydrozoa, Corynidae). Proc. Zool. Soc. Lond. 127:479-487. http://dx.doi.org/10.1111/j.1096-3642.1956.tb00483.x

VANNUCCI, M. \& REES, W.J. 1961. A revision of the genus Bougainvillia (Anthomedusae). Bolm Inst. Oceanogr., Univ. S. Paulo 11:57-100. 
VANNUCCI-MENDES, M. 1946. Hydroida Thecaphora do Brasil. Arq. Zool., Estado São Paulo 4(14):535-597.

VERVOORT, W. 1946. Exotic hydroids in the collection of the Rijksmuseum von Natuurijke Historie and the Zoological Museum at Amsterdam. Zool. Meded. 26:287-351.
VERVOORT, W. 1959. The Hydroida of the tropical West Coast of Africa. Atlantide Rep. 5:211-325.

WERNER, B. 1963. Effect of some environmental factors on differentiation and determination in marine Hydrozoa, with a note on their evolutionary significance. Ann. N.Y. Acad. Sci. 105:461-468.

Recebido em 28/08/2010 Versão reformulada recebida em 09/05/2011

Publicado em 22/06/2011 